\title{
Exploring Working Group's Psychological Subjectivity on Public Smart Work Services in a Cloud-based Social Networking
}

\author{
Ki Youn Kim ${ }^{1}$ and In Kuk Song ${ }^{2 *}$ \\ ${ }^{1}$ Department of Marketing Big Data, Mokwon University, Daejeon, South Korea \\ [e-mail: gracekykim@mokwon.ac.kr] \\ ${ }^{2}$ Business Administration, Dankook University, Yongin, South Korea \\ [e-mail: iksong@dankook.ac.kr] \\ *Corresponding author: In Kuk Song
}

Received November 5, 2020; accepted November 30, 2020; published December 31, 2020

\begin{abstract}
Recently, the COVID 19 pandemic has affected on our daily lives and society in many ways. Specifically, it has brought rapid changes in the working environment from office working to smart telecommuting. In addition, cloud computing technology and services not only provided ubiquitous access, but also led to a sharing of information, internal-external communication channels, telework, and innovative smart work for the business process. As a result, smart work services based on social cloud networking have spread to the public sector. However, existing academic research examining smart work merely remains to focus on the theoretical conceptualization or to deal with merely several examples of private views. Best practices of smart work services based on cloud computing technology in the public field rarely exists. Moreover, many studies have been differently measured the values of smart work for private and public sectors depending on organizational singularities. Therefore, the study aims to define new theoretical implications and to explore future business strategies and policy directions based on a technical working group's personal psychological subjectivity. The research applied Q methodology, and selected five public organizations in Korea, that they have adopted or currently plan to adopt some part of smart work services.
\end{abstract}

Keywords: Smart Work, Cloud-Based Social Networking, Psychological Subjectivity, Q methodology, Case Study, Working Group, Interpretative Research, Strategic Policy

The present research was conducted by the research fund of Dankook University in 2017. 


\section{Introduction}

In the era of COVID 19, smart work services are becoming more diversified and spreand not only in private companies but also in public beyond the spectrums of application and values in cloud computing and the social networking environment. Mobile cloud computing (MCC) technologies, which have evolved from the inherencies of cloud computing, can be deemed a convergence of mobile and cloud computing. IEEE MCSMS(2020) emphasized that MCC is one of hottest new technologies today in both academia and industry, with MCC market value of US $\$ 9.5$ billion in 2014 and with more than 1 trillion cloud-ready devices in the next four years [1]. In particular, the data suggest that Korea will dominate the highest market share among all of Asia. The rapid growth of state-of-the-art ICT and telecommunication technologies in Korea has accelerated thanks to various smart work booms based on cloud-based social networking [2].

Both private companies and public organizations have realized the importance of smart work, and smart work has now become a next-generation business value proposition and essential information resource that leads to changes in work processes or enterprise organizational cultures. Concretely, the core technologies of the cloud and social networks have led to ubiquitous connections wherever and wherever smart work can access and share information, integrated communication channels both internal and external to organizations, remote working and mobile offices, and innovatively redesigned business processes to actualize business intelligence. For now, the market of smart work services is formed by several market-leading companies in the private sector, meaning it takes more time to universalize it to the public sector [3].

Because the features of the preliminary smart work market affect trends in the field of academic research, previous research on smart work services tends to focus on the application of the definition of theoretical concepts or case studies in private companies. Furthermore, compared to the cumulative quantities of case studies involving privates companies, the case studies of public organizations are relatively insufficient. Actual differences exist in terms of the functions and values of the practical use of smart work between private companies and public organizations. Such differences should be dealt with or measured in different ways due to the unique differentiations and singularities in organizational visions, goals, business units or functions, and cultures. Thus, this timely and relevant study intensively studies five cases of Korean public organizations that have introduced or have plans to introduce some part of smart work services whereas public organizations have more gradually accepted the application of smart work.

The purpose of this study is to investigate the desirable future business strategies and policy directions based on an interpretative and psychological subjectivity study of what individual specialists in technical working groups think while being deeply engaged in smart work based on personal awareness, tendencies, subjective values, beliefs, preferences, satisfaction, psychological traits, using patterns, etc. By applying Q methodology, this study is able to derive thinking structural types called schemata in terms of what respondents consider the most important factors to maximize values of smart work in the field as well as suggested theoretical implications to define unique attributes of each type. This is a person-oriented approach by which each respondent tries to exclude his/her opinions as a member of an organization or industry, to the greatest extent possible, and rely only on subjective or 
psychological thoughts in his/her mind; as a result, this approach can derive more objective and appropriate research results and implications applying reality.

\section{Theoretical Background}

\subsection{Cloud-based Smart Work}

Smart work refers to a way to perform tasks and directly connect to the individual, joint, or multiple efforts for creating a "great work place" (GWP), which saves significant time and achieves the organizational goal faster. In addition, employees can ultimately work happily and conveniently by using cloud computing, social networks, and various state-of-the-art information technologies $[4,5]$.

From an academic perspective, many scholars have identified the necessities and effects of smart work introduction. The development of cloud-based smart work services or technologies can enhance the seamless integration of networking processes that were previously impossible in work processes, such as reducing working spaces, cutting costs, increasing productivity, enhancing individual workers' lives, reducing traffic, and reducing energies. Park and Kim (2013) concluded that smart work environments should be decentralized and the authority transplanted and appropriate for network organization, rather than relying on previous organizational culture and working environments [6].

Table 1. Smart work types in the public sector

\begin{tabular}{|c|c|c|c|}
\hline Class & Smart work center & Remote working & Mobile working \\
\hline Way of working & $\begin{array}{l}\text { Go to appointed office } \\
\text { (smart work center) }\end{array}$ & $\begin{array}{c}\text { Access organization's } \\
\text { information network system } \\
\text { directly from home }\end{array}$ & $\begin{array}{c}\text { Perform tasks using smart } \\
\text { devices }\end{array}$ \\
\hline Advantages & $\begin{array}{c}\text { Convenient way of } \\
\text { working, good security } \\
\text { Similar office environment } \\
\text { as head office } \\
\text { Able to work while } \\
\text { avoiding housework and } \\
\text { infant care } \\
\text { Greater concentration }\end{array}$ & $\begin{array}{l}\text { Office space not required } \\
\text { Reduced commuting time } \\
\text { and transportation costs } \\
\text { Reduced operational/ } \\
\text { management fees for head } \\
\text { office } \\
\text { Faithful to both work and } \\
\text { family life }\end{array}$ & $\begin{array}{c}\text { Convenient for } \\
\text { environments with } \\
\text { many meetings and } \\
\text { movements } \\
\text { Saves time with simple } \\
\text { work }\end{array}$ \\
\hline Disadvantages & $\begin{array}{l}\text { Expenses for extra office } \\
\text { spaces and facilities } \\
\text { Need to organize related } \\
\text { laws and systems } \\
\text { Need to build management } \\
\text { organizations and systems }\end{array}$ & $\begin{array}{l}\text { Concerns about reduced } \\
\text { synergy with coworkers and } \\
\text { job satisfaction } \\
\text { Limited tasks performed due } \\
\text { to insufficient security }\end{array}$ & $\begin{array}{l}\text { Tightened control of } \\
\text { workers by } \\
\text { location-tracking services } \\
\text { with smartphones, etc. } \\
\text { Impossibility to complete } \\
\text { intensive work }\end{array}$ \\
\hline
\end{tabular}

(Source: Won Dong Wook, 2012 [7])

\subsection{Cloud Computing for Smart Work}

Academically, cloud computing can be defined from various perspectives. Bisciglia (2006) explained that cloud computing was developed for IT resources management that users tried to utilize capacity of individual computing server. Ian T. Foster explained that cloud computing 
is a large-scale distributed computing paradigm in which computing power, storage, platform, and services are virtualized and provided on the internet; it also has dynamic expandability and economy of scale. Generally, cloud computing is a concept in which virtualized computing uses information system resources, such as databases, software, hardware, platform, network, and infrastructures, in various data centers (IDCs) via the internet in terms of services that users need to use at any time and in any place [8].

Cloud computing systems offer many advantages, including the speed of resource allocation, increased computing applications, diversification of work-load management systems, and productivity and efficiency in operations (e.g., sharing and movement of data between servers) [9]; in addition, it attracts attention as it is a green energy computing device for pursuing energy-saving effects in environmental aspects. The rapid development of IT changes humans, companies, and societies and has led to the smart IT era based on mobility. The inclusion of network PCs, social network services, and smart work based on cloud computing is extending to propel changes in people's lifestyles and companies' business environments. Smart IT is defined by focusing on the field, sharing information, changing work patterns, etc., to actualize personal offices as well as combined environments of mobile offices and desk offices $[10,11]$.

\subsection{Q Theory: Psychological Subjectivity Approach}

Q theory, a typical approach to qualitative research, discovers and interprets human attributes such as feelings, preferences, emotions, and ideals $[12,13]$. It is useful for investigating the self or subjectivity to understand humans' experiences and attitudes. It is simultaneously a methodology, model, and theory, depending on the research perspectives. McKeown and Thomas (1988) defined subjectivity as communication about the perspective of a person [14]. In other words, it is a psychological cognitive structure (schemata) expressed in terms of questions related "to me" and "in my opinion" in order to identify subjective communication based on reality and the experienced meaning of one person through an internal frame of reference $[15,16]$.

The variable of $\mathrm{R}$ research is a measurement item or stimulus, but the variable of $\mathrm{Q}$ research is a person. $\mathrm{R}$ research aims to infer features of a population from the features of a sample (i.e., person), and it is sufficient for systemically collecting many representation samples of a specific population. Meanwhile, the sampling process of $Q$ research is very complex and complicated. Researchers should pay particular attention to motivating and stimulating Q sorters to ensure that they can express all of their subjectivity. Yet Q research offers several advantages. For example, it enables the researcher to understand a person's (i.e., subject) psychological tendency related to the object of the study in terms of accidents, people, and phenomena, both intuitionally and structurally, and to present a categorizing procedure systematically and clearly. In addition, it is quantitative research based on a non-structured survey, although the results of Q can be quantified by Q sorting. In short, Q research is a research about humans. It is ipsative research used to structuralize intra-individual significances in many items, but not the inter-individual differences of one stimulating item [17-19]. Ipsative, meaning "off the self," is a measuring method used to classify ideas from the best agreement (+) to the least agreement (-) on more than two statements (normally). 


\section{Research Design and Process}

$\mathrm{Q}$ research is analysis process to give extracted stimulating item sample ( $\mathrm{Q}$ sample) from stimulating item population ( $\mathrm{Q}$ population) in the form of cards to extracted people (P sample) from certain population (P population), and to distribute them in order of priority ( $\mathrm{Q}$ sorting). $\mathrm{Q}$ sample is things or statement which respondents (P sample or $\mathrm{Q}$ sorter) should distribute. Research process is composed of 6 steps; to build Q population, to detect Q sample from $\mathrm{Q}$ sample, $\mathrm{Q}$ sorting and data processing, to analyze $\mathrm{Q}$ factor, to find out type and interpret.

\subsection{Step 1: Q Population and Q Sample}

The most important step in Q research is to build Q sample from Q population. Essentially, Q research focuses on categorizing subjectivity of $\mathrm{P}$ sample, and does not infer population of stimulating items like $\mathrm{R}$ research. To build population in $\mathrm{Q}$ research is to collect every stimulating item about research question and it starts from definition of population. Researcher should collect specific statements, which will be Q population with physically heavy works, depending on interview and document researches. Generally, academic references tend to be collected based on facts in the past, so they can be used for supporting means.

To collect Q population statements, the study conducted in depth interview of technical working group and literature or documents researches. Consequently, we get comprehensive statements of about $130 \mathrm{Q}$ population items. To derive $32 \mathrm{Q}$ sample items from Q population, first we delete same statements with Q population and categorize remaining statements of Q population into 19 categories by sub-subjects. This categorization assured that statements in $\mathrm{Q}$ sample are not biased toward certain categories and reflect overall respondents' opinions.

Table 2. Q Samples Compressed from Q Population

\begin{tabular}{|c|c|}
\hline No. & Statements \\
\hline 1 & $\begin{array}{l}\text { Big organizations tend to select private clouds to build their own group system; SMEs tend to select public } \\
\text { clouds. }\end{array}$ \\
\hline 2 & $\begin{array}{l}\text { Work and life balance (WLB) should be prepared to enhance members' physical and psychological job } \\
\text { satisfaction. }\end{array}$ \\
\hline 3 & $\begin{array}{l}\text { When shifting from a work area that uses a lot of paper in public organizations, a paperless work } \\
\text { environment requires advance support and considerate policies. }\end{array}$ \\
\hline 4 & $\begin{array}{l}\text { Managers' awareness of smart work process and infrastructure maintenance should be increased to } \\
\text { encourage members' voluntary job motivations. }\end{array}$ \\
\hline 5 & $\begin{array}{l}\text { Smart work is not possible without the active participation of members and should be designed to } \\
\text { experience changes from the beginning. }\end{array}$ \\
\hline 6 & $\begin{array}{l}\text { Using change management or campaign education is critical to strengthen affective communication, a } \\
\text { sense of belonging, and connections for actualizing smart work }\end{array}$ \\
\hline 7 & $\begin{array}{l}\text { It is necessary to support self-managing systems, culture, and environmental maintenance to enable } \\
\text { members to care for others' time and lead their tasks. }\end{array}$ \\
\hline 8 & $\begin{array}{l}\text { When building a self-managing system, roles or responsibilities should be clear and members' identities } \\
\text { and motivations assigned. }\end{array}$ \\
\hline 9 & $\begin{array}{l}\text { To extend a paperless office by smart work, it is important to eliminate waste elements and aim for green } \\
\text { IT environments. }\end{array}$ \\
\hline 10 & The purpose of providing technological support for smart work is to create value-added work processes. \\
\hline 11 & Ultimately, delicate technology to actualize a smart mobile office should be prepared. \\
\hline 12 & $\begin{array}{l}\text { When supporting green security platform/network technology, it is essential to build a smart work } \\
\text { infrastructure to guarantee security and reliability from malignant tracking. }\end{array}$ \\
\hline 13 & $\begin{array}{l}\text { With the early adoption and spread of site management organization (SMO), it is necessary to provide } \\
\text { supporting policies in the productive application of mobile services. }\end{array}$ \\
\hline 14 & $\begin{array}{l}\text { In smart work environments, it is essential to improve organizational culture to use creative collective } \\
\text { intelligence like crowd sourcing. }\end{array}$ \\
\hline
\end{tabular}




\begin{tabular}{|c|c|}
\hline 15 & $\begin{array}{l}\text { Cloud-based smart work can rapidly handle business, but it is insufficient in information reliability and } \\
\text { security so that security system is required in each step of activation. }\end{array}$ \\
\hline 16 & $\begin{array}{l}\text { To promote governmental or private councils, they should support the adoption of cloud-based smart work } \\
\text { and develop many successful cases. }\end{array}$ \\
\hline 17 & $\begin{array}{l}\text { Actualizing smart work can only be possible after new successful cases of creating value spreads through } \\
\text { organizations' internal/external creative communication. }\end{array}$ \\
\hline 18 & Fundamental systems should be used to evaluate the performance of smart work. \\
\hline 19 & $\begin{array}{l}\text { The innovation of work process should utilize remote work and smart work centers due to advanced } \\
\text { telework. }\end{array}$ \\
\hline 20 & $\begin{array}{l}\text { Promotion projects appropriate during the early stage of smart work should be adopted for smart work } \\
\text { centers to spread them to all organizations and concentrate the resources and capabilities on the projects. }\end{array}$ \\
\hline 21 & $\begin{array}{l}\text { As with early cases of ERP systems, smart work should be supported to go through module customization } \\
\text { in companies' environments until they reach a stable stage. }\end{array}$ \\
\hline 22 & $\begin{array}{l}\text { It is important to redesign the smart work process according to cloud environments not only to maintain, } \\
\text { but also to modify existing work processes. }\end{array}$ \\
\hline 23 & $\begin{array}{l}\text { Smart work should be visualized via innovation in physical workspace management (e.g., sharing desks } \\
\text { from free address, hot desking). }\end{array}$ \\
\hline 24 & $\begin{array}{l}\text { Changes to work-time management should be made based on systems such as the core hour, time off, } \\
\text { flexible work time, and time buffer management. }\end{array}$ \\
\hline 25 & $\begin{array}{l}\text { There will be positive effects to reduce energies or improve the quality of lives because spreading } \\
\text { cloud-based smart work can produce various kinds of work patterns. }\end{array}$ \\
\hline 26 & $\begin{array}{l}\text { Smart work is not limited by workplace, and there should be assisting tools software to evaluate } \\
\text { performance in terms of quantity and quality. }\end{array}$ \\
\hline 27 & To activate cloud services, the standards and criteria of information or documents should be redefined. \\
\hline 28 & $\begin{array}{l}\text { Smart work will make business communication without facing each other common, and smart work can } \\
\text { prevent team work and group solidarity. }\end{array}$ \\
\hline 29 & $\begin{array}{l}\text { SMEs find it hard to invest in basic IT, such as ERP, SCM, and CRM, and it is indispensable to give } \\
\text { political support in new information areas like SMO. }\end{array}$ \\
\hline 30 & $\begin{array}{l}\text { Mobile offices use dependent technologies to platform, such as Active } \mathrm{X} \text { and Flash, and there should be } \\
\text { support for the latest devices in early stages. }\end{array}$ \\
\hline 31 & $\begin{array}{l}\text { There will be demands for the application of open technology and standardization to solve compatibility } \\
\text { problems due to independent platforms by each business unit. }\end{array}$ \\
\hline 32 & $\begin{array}{l}\text { To protect the privacy of individual members, physical space elements for smart work are needed to } \\
\text { enhance work concentration. }\end{array}$ \\
\hline
\end{tabular}

\subsection{Step 2: Selection of $\mathbf{P}$ sample}

$\mathrm{P}$ population is a group of respondents who conduct $\mathrm{Q}$ sorting in $\mathrm{Q}$ sample, and $\mathrm{P}$ sample is respondents participating Q sorting actually. Increasing number of $\mathrm{P}$ sample causes statistical problems, so Q methodology is based on small sample doctrine (Stephenson, 1953). Conditions to select $\mathrm{P}$ sample is good to select people who have various opinions such as someone who has special interest on subject of study, someone who can suggest dispassionate opinions like judges or jury, someone who is present authorities and experts, someone who has class interest, someone who is un-interested or uninformed and etc. [20]. This study selected $P$ sample 34 persons who belonged to professional technical working group in cloud-based smart work of five public organizations. It is a sampling method that researches selected proper samples on purpose and get recommended samples from others increasing samples like rolling snowball [21].

\subsection{Step 3: Q Sorting and Data Collection}

Q sorting is similar to rank ordering process. Typical Q sorting starts from presenting a bunch of Q sample to respondents (Q sorter), and they starts to arrange simulating items in order of importance in subject perspective. It is not a process to get binary opinions (favor/oppose) of respondents in Q sample; it is a process of classification into forced distribution. In short, 
result of Q sorting shows differences of respondents as 'their own subjective opinions about problems'. This study followed a traditional card align principle of Q research, but used Flash Q software (offline version) after redesigning in order to get effective sorting data which can overcome physical time and geographic difference of $P$ sample [22].

Flash Q is an open source sorting tool in way of 'draw-and-drop' which is similar with sorting paper on an offline tabletop. To observe Q sorting process of respondents directly, researchers collected data using remote function of instant messenger and face-to-face interview. Sorting time per person of $\mathrm{P}$ sample was good to record $30-40$ minutes in average despite of a little gap between respondents. Shape of distribution was composed of 9 point scale; 'most disagree' (-4), 'neutral' (0), 'most agree' (+4).

Table 3. Q Sorting Distribution and Score

\begin{tabular}{|c|c|c|c|c|c|c|c|c|c|}
\hline Raw Score & $\mathbf{- 4}$ & $\mathbf{- 3}$ & $\mathbf{- 2}$ & $\mathbf{- 1}$ & $\mathbf{0}$ & $\mathbf{1}$ & $\mathbf{2}$ & $\mathbf{3}$ & $\mathbf{4}$ \\
\hline Calculative Score & 1 & 2 & 3 & 4 & 5 & 6 & 7 & 8 & 9 \\
\hline Frequency & 3 & 4 & 4 & 5 & 5 & 5 & 4 & 4 & 3 \\
\hline
\end{tabular}

\subsection{Step 4: Data processing and Analysis}

Before $\mathrm{Q}$ factor analysis, each scale of Table 3 should be changed into scores to be given 9 points to 'the most disagree' (-4), 'neutral' $(0)$, 'the most agree' $(+4)$ for data processing. To categorize smartphone users, Q analysis of collected data in $\mathrm{Q}$ sorting was conducted in correlation analysis, principle component analysis, varimax rotation by QUANL PC program. This analysis is a process to combine people with similar thoughts about certain subject. In other words, it is not a grouping of people sharing certain features, but it is a categorizing by standards of subjective features characterized in a person [23].

\section{Results and Interpretation}

\subsection{Q Factor Analysis}

With 3 kinds of category interpretations called EAC (Efficiency, Autonomy, Collaboration), theoretical conception about strategic policy direction of smart work future model are proposed. As seen in Table 4, there are 4 kinds of smartphone users. Eigen value is a square sum of each load values, and other figures indicate variance, total variance and cumulative variance. Each eigen value of 3 types is 5.7975, 4.6260, 2.5605 in order. As a result of analysis, eigen values for each factor are over 1.0 desirably, explanation power of all factors which cumulative variance indicates is $0.3819(38 \%)$. At this point, the reason why first value of factor is higher than others is that the number of $\mathrm{P}$ sample is bigger. Also explanation power gets lower, but eigen values or variables are affected by the number of respondents statistically, so that it is meaningless in Q. In Q study, understanding subjectivity of P sample which has weighted value of factors $>1.0$ showing ideal tendency is important to increase explanation power of type interpretation. 
Table 4. Results and Typologies with QUANL Analysis

\begin{tabular}{|c|c|c|c|c|c|}
\hline \multicolumn{6}{|c|}{ Type I (N=8) } \\
\hline$P_{n}$ & Gender & Age & Affiliation & Business Task & $\begin{array}{l}\text { Factor } \\
\text { Weight }\end{array}$ \\
\hline$P_{n}$ & Gender & Age & Affiliation & Business Task & Factor weight \\
\hline $\mathrm{P}_{1}$ & Male & 52 & $\mathrm{~A}$ & Center director & 3.3027 \\
\hline $\mathrm{P}_{2}$ & Male & 47 & $\mathrm{~A}$ & Information manager & 4.8432 \\
\hline $\mathrm{P}_{3}$ & Male & 44 & $\mathrm{~A}$ & IS manager & 1.4700 \\
\hline $\mathrm{P}_{4}$ & Male & 50 & $\mathrm{~A}$ & Operating planning & 3.4604 \\
\hline $\mathrm{P}_{5}$ & Female & 20 & $\mathrm{~A}$ & materials mgt. & 4.6721 \\
\hline $\mathrm{P}_{6}$ & Female & 33 & $\mathrm{~A}$ & Data mgt. & .4447 \\
\hline $\mathrm{P}_{7}$ & Female & 36 & $\mathrm{~A}$ & Data mgt. & .9840 \\
\hline $\mathrm{P}_{8}$ & Female & 35 & $\mathrm{~A}$ & Data mgt. & 2.0275 \\
\hline \multicolumn{2}{|c|}{ Eigen value } & \multicolumn{4}{|c|}{5.7975} \\
\hline \multicolumn{2}{|c|}{ Variance } & \multicolumn{4}{|c|}{.1705} \\
\hline \multicolumn{2}{|c|}{ Cumulative variance } & & & .1705 & \\
\hline \multicolumn{6}{|c|}{ Type II (N=13) } \\
\hline$P_{n}$ & Gender & Age & Affiliation & Business Task & Factor weight \\
\hline $\mathrm{P}_{9}$ & Male & 33 & A & ERP & 1.0345 \\
\hline $\mathrm{P}_{13}$ & Female & 35 & $\mathrm{~A}$ & E-procurement & 0.3860 \\
\hline $\mathrm{P}_{14}$ & Female & 42 & $\mathrm{~A}$ & Accounting system & 1.3017 \\
\hline $\mathrm{P}_{16}$ & Female & 45 & $\mathrm{~A}$ & ICT education & .7927 \\
\hline $\mathrm{P}_{17}$ & Female & 38 & $\mathrm{~B}$ & Business Manager & .0875 \\
\hline $\mathrm{P}_{21}$ & Male & 40 & $\mathrm{~B}$ & Business Strategy & .5021 \\
\hline $\mathrm{P}_{24}$ & Male & 41 & $\mathrm{E}$ & Marketing PM & .3248 \\
\hline $\mathrm{P}_{27}$ & Female & 39 & $\mathrm{C}$ & Cloud system & .6485 \\
\hline $\mathrm{P}_{28}$ & Male & 38 & $\mathrm{C}$ & Homepage mgt. & .9429 \\
\hline $\mathrm{P}_{29}$ & Female & 29 & $\mathrm{C}$ & System development & 1.5256 \\
\hline $\mathrm{P}_{30}$ & Male & 33 & $\mathrm{C}$ & Security/ERP & 1.2968 \\
\hline $\mathrm{P}_{35}$ & Male & 40 & $\mathrm{D}$ & Efficient management & 1.5935 \\
\hline $\mathrm{P}_{36}$ & Male & 31 & $\mathrm{C}$ & Integrated maintenance & 1.2108 \\
\hline \multicolumn{2}{|c|}{ Eigen value } & \multicolumn{4}{|c|}{4.6260} \\
\hline \multicolumn{2}{|c|}{ Variance } & \multicolumn{4}{|c|}{.1361} \\
\hline & \multirow{2}{*}{\multicolumn{4}{|c|}{ Type III (N=13) }} \\
\hline \multicolumn{2}{|c|}{ Cumulative variance } & \multicolumn{2}{|c|}{ Type III (N=13) } & & \\
\hline $\mathrm{P}_{\mathrm{n}}$ & Gender & Age & Affiliation & Business Task & Factor weight \\
\hline $\mathrm{P}_{10}$ & Male & 47 & $\mathrm{~A}$ & Business mgt. & .3662 \\
\hline $\mathrm{P}_{11}$ & Male & 18 & $\mathrm{~A}$ & Complaints system & .2449 \\
\hline $\mathrm{P}_{12}$ & Male & 27 & $\mathrm{~A}$ & IS development & .5460 \\
\hline $\mathrm{P}_{15}$ & Male & 46 & $\mathrm{~A}$ & ISP/budget & .5010 \\
\hline $\mathrm{P}_{18}$ & Male & 30 & $\mathrm{~A}$ & IT commodities & .4168 \\
\hline $\mathrm{P}_{20}$ & Male & 49 & $\mathrm{~B}$ & ISP/assessment & .3700 \\
\hline $\mathrm{P}_{22}$ & Male & 39 & $\mathrm{~B}$ & Long-term vision & .8992 \\
\hline $\mathrm{P}_{23}$ & Male & 42 & $\mathrm{~B}$ & IT mgt. & 1.3743 \\
\hline $\mathrm{P}_{25}$ & Male & 49 & $\mathrm{~F}$ & CS mgt. & .3870 \\
\hline $\mathrm{P}_{31}$ & Male & 46 & $\mathrm{C}$ & ISP/budget & .3304 \\
\hline $\mathrm{P}_{32}$ & Male & 46 & $\mathrm{C}$ & Business affairs & .8141 \\
\hline $\mathrm{P}_{33}$ & Male & 45 & $\mathrm{C}$ & HR/construction & .3131 \\
\hline $\mathrm{P}_{34}$ & Female & 34 & $\mathrm{C}$ & Knowledge mgt. & 1.2545 \\
\hline \multicolumn{2}{|c|}{ Eigen value } & \multicolumn{4}{|c|}{2.5605} \\
\hline \multicolumn{2}{|c|}{ Variance } & \multicolumn{4}{|c|}{.0753} \\
\hline \multicolumn{2}{|c|}{ Cumulative variance } & \multicolumn{4}{|c|}{.3819} \\
\hline
\end{tabular}

※ A(Korea Rail Network Authority), B(Korea Creative Content Agency), C(National Research Foundation of Korea), E(small businesses, Digital Marketing), F(Oracle Korea) 


\subsection{Interpretative Typologies}

\subsubsection{Type 1: Efficient Optimization of Business by BRP}

Type 1 is a person who supports to activate smart work. Experts in this type agree to spread smart work organizations based on cloud in overall industries to maximize working efficiency and productivity. To visualize business performance and expected effects of smart work technology, innovation of infrastructure in view of BRP is essential to redesign function of works and processes in organization. In short, smart work is a technical resource and strategic tool to maximize efficiency and effectiveness of organization. They think reason of existing smart work connecting to 'value-added productivity of working process and efficient optimization of business' (Q10, z1.54), and emphasize importance of smart work as a business intelligence (BI) tool for creating new and inventive values. Following principles to activate smart work, Type 1 supports strongly the ideas that 'policy projects are necessary to introduce smart work center in early stage of smart work, and they should be based on keynote of promotion policy to spread to every organization' (Q20, $\mathrm{z}=1.57)$. These results indicate concrete strategies to optimize process directly to increasing work efficiency, which is an ultimate vision of smart work activation. 'Specialized physical space should be prepared like smart work center which can enhance concentration of members' (Q32, $\mathrm{z}=1.41)$. This indicates that redesigning of business working process based on smart work is not limited only on software or systems, but it covers physical spaces ranges.

In addition, it's essential 'to develop open technology and standardized policies which can solve problems of compatibilities between different platforms each business developed' (Q31, $\mathrm{z}=1.39$ ).It is a item to reflect experts' will in Type 1 to spread or activate smart work to overall industries. The reason they emphasized open platform and standardization is to suggest sustainable extensibility, not limited application of smart work for each business unit. Future direction of strategic policies of smart work Type 1 expects highlighted their progressive tendencies of awareness that they insists to reorganize smart work environments for cloud environments, not just maintaining and repairing existing system' (Q22, $\mathrm{z}=1.35$ ). In advancements of existing telework or remote work, they agree that 'innovation of working process is th e most urgent project to activate smart work in earnest' $(\mathrm{Q} 19, \mathrm{z}=1.26)$. Basically they think that 'there is a necessity of supports or political considerations to make works based on paper paperless in public organizations' (Q3, $\mathrm{z}=1.01)$.

On the other hand, Q items Type 1 disagreed can tell their interests comparing to other types. They disagreed fragmentary smart work policies such as 'latest device supporting policy applied in mobile smart work platform' (Q30, $\mathrm{z}=-1.63)$. We have learned that Type 1 is paying attention to overall innovation in designing specialized process of new smart work technologies. But content of Q 30 is opposite. There is a thread of connection in their opinion that they support to introduce smart work with the goal to enhance work efficiency and productivity, with strong objection against items such as 'cloud smart work can make working process faster, but there should be security system to activate in poor information reliability $(\mathrm{Q} 15, \mathrm{z}=-1.60)$ ' or 'standards and criteria of creating information or documents level' $(\mathrm{Q} 15$, $\mathrm{z}=-1.60$ ). In addition, they more focus on 'marketability' to enhance performance or 'market competition' in business administration perspective than building software infrastructure which can guarantee security from malignant tracking by supports of green security platform or network technologies (Q12, $\mathrm{z}=-1.45)$. It indicates their innovative will to change into productive organizations to react like private companies in new trends of market applying smart work actively even in public organizations. 
Table 5. Z-scores and Q-items descriptions Type 1(z-score $> \pm 1.00)$

\begin{tabular}{|c|l|c|}
\hline Qn & \multicolumn{1}{|c|}{ Q Statements } & z-Score \\
\hline \multicolumn{2}{|c|}{ Positive statements (+) } & 1.54 \\
\hline 10 & $\begin{array}{l}\text { The purpose of providing technological support for smart work is to create value-added } \\
\text { work processes. }\end{array}$ & 1.41 \\
\hline 32 & $\begin{array}{l}\text { To protect the privacy of individual members, physical space elements for smart work are } \\
\text { needed to enhance work concentration. }\end{array}$ & 1.39 \\
\hline 22 & $\begin{array}{l}\text { There will be demands for the application of open technology and standardization to solve } \\
\text { compatibility problems due to independent platforms by each business unit. }\end{array}$ & $\begin{array}{l}\text { It is important to redesign the smart work process according to cloud environments not only } \\
\text { to maintain, but also to modify existing work processes. }\end{array}$ \\
\hline 19 & $\begin{array}{l}\text { The innovation of work process should utilize remote work and smart work centers due to } \\
\text { advanced telework. }\end{array}$ & 1.35 \\
\hline 3 & $\begin{array}{l}\text { When shifting from a work area that uses a lot of paper in public organizations, a paperless } \\
\text { work environment requires advance support and considerate policies. }\end{array}$ & 1.01 \\
\hline & \multicolumn{1}{|c|}{ Negative statements (-) } \\
\hline 30 & $\begin{array}{l}\text { Mobile offices use dependent technologies to platform, such as Active X and Flash, and } \\
\text { there should be support for the latest devices in early stages. }\end{array}$ & -1.63 \\
\hline 15 & $\begin{array}{l}\text { Cloud-based smart work can rapidly handle business, but it is insufficient in information } \\
\text { reliability and security so that security system is required in each step of activation. }\end{array}$ & -1.60 \\
\hline 27 & $\begin{array}{l}\text { To activate cloud services, the standards and criteria of information or documents should be } \\
\text { redefined. }\end{array}$ & -1.52 \\
\hline 12 & $\begin{array}{l}\text { When supporting green security platform/network technology, it is essential to build a smart } \\
\text { work infrastructure to guarantee security and reliability from malignant tracking. }\end{array}$ & -1.45 \\
\hline 11 & Ultimately, delicate technology to actualize a smart mobile office should be prepared. & -1.33 \\
\hline 13 & $\begin{array}{l}\text { With the early adoption and spread of site management organization (SMO), it is necessary } \\
\text { to provide supporting policies in the productive application of mobile services. }\end{array}$ & -1.06 \\
\hline
\end{tabular}

\subsubsection{Type 2: Self-driven Autonomy with HRD/HRM}

Q items in Type 2 were converted into various keywords; motivation and autonomy of human resources (members). Type 2 also showed same direction of macro strategies to activate smart work. Type 1 discusses future direction of smart work in the perspective of organizational system; on the contrary, Type 2 thinks that capacities of people who work in organizational system is the most important, that is, they consider the perspective of HRD/HRM mostly. In short, successful application of smart work depends on self-driven working management of members in organization. It indicated that public officials work with self-driven autonomy because public organizations are in stiffen vertical bureaucratic system relatively compared to general workers in privates companies in reality. Concrete strategies that Type 2 suggested for activation of smart work were listed in Q items they agreed mostly.

Above all, experts in Type 2 support to have 'change management programs or Campaign education which can strengthen affective communications, sense of belongings, and connections between members' $(\mathrm{Q} 6, \mathrm{z}=1.46)$ to actualize smart work. They insist that smart work can be actualized not by technology, but by human. 'Self-driven autonomy system they pursue is based on roles of members, clear responsibilities, establishing identity, motivation of work' $(\mathrm{Q} 8, \mathrm{z}=1.29)$. They agreed a similar item, which said that 'There should be changes of working time management based on system such as Core hour, time-off, flexible time work, time buffer management and etc' $(\mathrm{Q} 24, \mathrm{z}=1.17)$. Comparing change management of members' mindset to private organizations, it can reflect a reality of nonflexible organizational cultures in management-oriented structure. Therefore, in public organizations 'acceptance of new culture and technology like Smarts work is not possible without active participations of members' $(\mathrm{Q} 5, \mathrm{z}=1.11)$. For this reason, Type 1 emphasized milestone that they insist to spread smart work into whole industries by redesigning working process from early stage, but 
Type 2 supports to strengthen HRM program for members to experience changes in early stage. And they also emphasized not only members but also 'Managers' awareness should be raised for developing smart work process and infra maintenance to encourage voluntary job motivations of members' $(\mathrm{Q} 4, \mathrm{z}=1.02)$.

Analyzing items Type 2 disagreed, we can find different tendencies in awareness of Type 1 and 2. They showed opposite tendencies in the problem of 'necessity of physical space specialized in smart work' (Q32) and 'supports of openness and compatibility between different platforms of each businesses' (Q31). On the other hand, both of them showed strong objection on the item, which said that 'Smart work will bring communications without facing each other in business commonly, and smart work can prevent team work and group solidarity' (Q28, z=-2.24) and it indicates that Type 2 also doesn't have hostility to activate smart work. About the perspective of SMO (site management organization), both types don't agreed on SMO supporting policies much. Only Type 1 disagreed supporting policies to adopt and spread of Site Management Organization (SMO), in productive application mobile services' (Q13, $\mathrm{z}=-1.06)$, and Type 2 showed hostility to discuss SMO new information supporting policies in consideration of economic environments of SMEs. The reasons why they don't agree to support latest mobile devices in early stage of smart work platform showed differences that Type 1 focuses on innovation of smart work process and Type 2 focuses on change managements of human resources.

Table 6. Z-scores and Q-items descriptions Type 2(z-score $> \pm 1.00)$

\begin{tabular}{|c|l|c|}
\hline Qn & \multicolumn{1}{|c|}{ Q Statements } & z-Score \\
\hline 6 & $\begin{array}{l}\text { Using change management or campaign education is critical to strengthen affective } \\
\text { communication, a sense of belonging, and connections for actualizing smart work }\end{array}$ & 1.46 \\
\hline 8 & $\begin{array}{l}\text { When building a self-managing system, roles or responsibilities should be clear and } \\
\text { members' identities and motivations assigned. }\end{array}$ & 1.29 \\
\hline 24 & $\begin{array}{l}\text { Changes to work-time management should be made based on systems such as the core hour, } \\
\text { time off, flexible work time, and time buffer management. }\end{array}$ & 1.17 \\
\hline 5 & $\begin{array}{l}\text { Smart work is not possible without the active participation of members and should be } \\
\text { designed to experience changes from the beginning. }\end{array}$ & 1.11 \\
\hline 4 & $\begin{array}{l}\text { Managers' awareness of smart work process and infrastructure maintenance should be } \\
\text { increased to encourage members' voluntary job motivations. }\end{array}$ & 1.02 \\
\hline 12 & $\begin{array}{l}\text { When supporting green security platform/network technology, it is essential to build a smart } \\
\text { work infrastructure to guarantee security and reliability from malignant tracking. }\end{array}$ & 1.01 \\
\hline & \multicolumn{1}{|c|}{ Negative statements (-) } \\
\hline 28 & $\begin{array}{l}\text { Smart work will make business communication without facing each other common, and } \\
\text { smart work can prevent team work and group solidarity. }\end{array}$ & -2.24 \\
\hline 32 & $\begin{array}{l}\text { To protect the privacy of individual members, physical space elements for smart work are } \\
\text { needed to enhance work concentration. }\end{array}$ & -2.18 \\
\hline 30 & $\begin{array}{l}\text { Mobile offices use dependent technologies to platform, such as Active X and Flash, and } \\
\text { there should be support for the latest devices in early stages. }\end{array}$ & -2.06 \\
\hline 29 & $\begin{array}{l}\text { SMEs find it hard to invest in basic IT, such as ERP, SCM, and CRM, and it is indispensable } \\
\text { to give political support in new information areas like SMO. }\end{array}$ & -1.46 \\
\hline 31 & $\begin{array}{l}\text { There will be demands for the application of open technology and standardization to solve } \\
\text { compatibility problems due to independent platforms by each business unit. }\end{array}$ & -1.08 \\
\hline
\end{tabular}

\subsubsection{Type 3: Macro Innovation of Organizational Culture or Environments First}

At last, experts in Type 3 of $\mathrm{P}$ sample discuss future policies of smart work in the perspective of macro organizational culture and environments. They think the success of smart work depends on whether cooperative organizational culture based on communities created or not. Comparing to Type 2, they focus on cooperative system between made by reforming of 
organizational culture system from individual-oriented change management. In short, to become organizations to actualize smart work, range of change is similar to awareness tendencies of Type 1 in the system perspective of transcriptional organization, but it is close to the perspective of Type 2 that subjects of change bring complete cooperative communities and innovation of organization to communicate and share between members.

Type 3 agreed on items such as 'Working and Life Balance (WLB) environmental changes which can enhance physical and psychological job satisfaction of members' $(\mathrm{Q} 2, \mathrm{z}=1.92)$, and necessity 'to support self-driven autonomy, culture and environments maintenance that members can care others' time and lead their tasks' $(\mathrm{Q} 7, \mathrm{z}=1.36)$ much. But comparing to experts in Type 1 and 2, distinctive characteristic is that they don't welcome to introduce or activate smart work completely like other 2 types. Their real awareness tendencies about smart work are based on conservative or defensive tendencies. These tendencies can be found in following $\mathrm{Q}$ items. They strongly agree that smart work will damage atmospheres in organization and group solidarity to promote non-face-to-face activities (Q28, $\mathrm{z}=1.42)$.

And their negative thoughts about smart work were reflected in many disagreed items. They showed strong objection on 'positive effects to reduce energies or to improve quality of lives' (Q25, $\mathrm{z}=-1.33$ ), because cloud smart work can produce various kinds of working patterns. They also disagreed on the item to visualize by innovation in physical working space management such as sharing desks of free address, hot desking and etc (Q23, z=-1.31). In addition, they showed opposite tendencies on items Type 1 who supported to activate smart work disagreed. Type 1 showed strong agreements on supporting technologies for smart work with the strong belief that smart work can create value-added working process, on the contrary, Type 2 showed emphatic rejections $(\mathrm{Q} 10, \mathrm{z}=-1.30)$. Their passive reactions on smart work cannot connect expectations of smart work performances naturally. In short, they object 'to establish policies to build systems for evaluation of smart work' (Q18, $\mathrm{z}=-1.16)$.

Table 7. Z-scores and Q-items descriptions Type 3(z-score $> \pm 1.00)$

\begin{tabular}{|l|l|c|}
\hline Qn & \multicolumn{1}{|c|}{ Q Statements } & z-Score \\
\hline \multicolumn{1}{|c|}{ Positive statements (+) } & 2.03 \\
\hline 6 & $\begin{array}{l}\text { Using change management or campaign education is critical to strengthen affective } \\
\text { communication, a sense of belonging, and connections for actualizing smart work }\end{array}$ & 1.92 \\
\hline 2 & $\begin{array}{l}\text { Work and life balance (WLB) should be prepared to enhance members' physical and } \\
\text { psychological job satisfaction. }\end{array}$ & 1.87 \\
\hline 28 & $\begin{array}{l}\text { Managers' awareness of smart work process and infrastructure maintenance should be } \\
\text { increased to encourage members' voluntary job motivations. }\end{array}$ & 1.42 \\
\hline 7 & $\begin{array}{l}\text { Smart work will make business communication without facing each other common, and } \\
\text { smart work can prevent team work and group solidarity. }\end{array}$ & 1.36 \\
\hline 8 & $\begin{array}{l}\text { It is necessary to support self-managing systems, culture, and environmental maintenance to } \\
\text { enable members to care for others' time and lead their tasks. } \\
\text { members' identities and motivations assigned. }\end{array}$ & 1.13 \\
\hline & $\begin{array}{l}\text { When shifting from a work area that uses a lot of paper in public organizations, a paperless } \\
\text { work environment requires advance support and considerate policies. }\end{array}$ & -1.86 \\
\hline 25 & $\begin{array}{l}\text { There will be positive effects to reduce energies or improve the quality of lives because } \\
\text { spreading cloud-based smart work can produce various kinds of work patterns. }\end{array}$ & -1.33 \\
\hline 23 & $\begin{array}{l}\text { Smart work should be visualized via innovation in physical workspace management (e.g., } \\
\text { sharing desks from free address, hot desking). }\end{array}$ & -1.31 \\
\hline 10 & $\begin{array}{l}\text { The purpose of providing technological support for smart work is to create value-added } \\
\text { work processes. }\end{array}$ & -1.30 \\
\hline 18 & Fundamental systems should be used to evaluate the performance of smart work. & -1.16 \\
\hline
\end{tabular}




\section{Conclusion and Discussion}

Cloud-based smart work technologies and systems are extending into not only private companies, but also public organizations. The range of applications and expectations based on smart mobility and cloud computing technologies is growing day by day in the era of the COVID-19 pandemic. This study selected smart work area experts from nine public organizations in Korea as the $\mathrm{P}$ sample and aimed to suggest political guidance and implications to explore the direction of future policies related to smart work. In particular, the research applied $\mathrm{Q}$ methodology to investigate overall distributed tendencies from the empirical view based on researchers' operational definition of research plans, drawing three conclusions to identify and categorize tendencies of cognitive construction (schema) - namely, experts' thought about future strategic policies for smart work. These results can provide strategic guidance for the direction of future-oriented developments that Korean adopters of smart work expect as well as the exploration of problems that can prevent smart work from further developing at this point.

As results of these analyses, Types 1 and 2 strategic politics agreed with the need to activate smart work. The first strategy is the efficient optimization of business by BRP. This strategy is based on the belief that cloud-based smart work organizations can maximize the efficiency and productivity of works, and experts strongly agreed to the need to extend smart work organizational systems in industries overall. The precondition for this is an infrastructural innovation to redesign the whole work process based on smart work environments using the BPR perspective. The range of process innovation is not limited to software or systems only; it covers physical spaces as well.

The second strategy is intended to activate smart work based on a self-driven autonomy with HRD/HRM. The experts explained that the motivation and autonomy of human resources (members) are important; employees' capacities in organizational systems are critical for the innovation of hardware and software processes in the future direction of smart work. The successful application of smart work is based on members' self-driven autonomy in organization. However, this also indicates the limitation of public organizations in reality that individuals have difficulties in self-driven autonomy because they have relatively stricter bureaucratic systems compared to private companies.

The last strategy is to build organizational culture and environmental innovation macroscopically. The experts who support this strategy discussed future policies of smart work from the perspective of macro organizational culture and environments. In other words, the successful application of smart work depends on whether cooperative organizational culture based on communities can be created or not. In addition, Types 1 and 2 focus on the cooperative system between members, which can be achieved by reforming the organizational culture system; on the other hand, they showed conservative or defensive tendencies toward the introduction of smart work or activation policies.

This Q study investigated members who use the smart work service in each department in the eight public organizations explored the psychological tendencies of individual members using smart work. The results of the study provide implications for not only the behavioral characteristics of members who use smart work services, but also psychological tendencies to public organizations, so that they can be used as a meaningful guideline for enhancing organizational capacity and performance using smart work. 


\section{Reference}

[1] IEEE MCSMS, "Mobile Cloud Computing systems, Management, and Security," in Proc. of the 6th International Workshop on Mobile Cloud Computing systems Management, and Security, 2020. Article (CrossRef Link)

[2] J. S. Kim, I. S. Suh, and C. W. Ro, "Technological trends and cases of mobile cloud services," Review of the Korea Contents Association, vol. 9, no. 1, pp. 36-42, 2011. Article (CrossRef Link)

[3] S. J. Eom, N. B. Choi, and W. J. Sung, "The use of smart work in government: empirical analysis of Korean experiences," Government Information Quarterly, vol. 33, no. 3, July 2016, pp. 562-571, 2016. Article (CrossRef Link)

[4] I. K. Song, "Subjectivity study on cloud-based smart work service of a quasi-government agency," Journal of Internet Computing and Services, vol. 15, no. 1, pp. 113-123, 2014. Article (CrossRef Link)

[5] Hyosung Group, Work Smart, 2014. [Online]. Available: https://blog.hyosung.com

[6] K. H. Park and Y. J. Kim, "Difference in acceptance level of smart work among tendencies of personal leadership styles," The Journal of Digital Policy and Management, vol. 11, no. 11, pp. 197-207, 2013. Article (CrossRef Link)

[7] D. W. Won, Prepare new smart work age, The Korea Transport Institute, KOTI Magazine on Transport, 2012.

[8] K. Y. Kim and Y. I. Yoon. "Comparative positioning of Korean network companies moving to converging cloud services," Advanced Science and Technology Letters, vol. 8, pp. 681-686, 2012.

[9] D. Valle-Cruz, "Public value of e-government services through emerging technologies," International Journal of Public Sector Management, vol. 32, no. 5, pp. 530-545. 2019. Article (CrossRef Link)

[10] S. Marston, Z. Li, S. Bandyopadhyay, J. Zhang, and A. Ghalsasi, "Cloud computing: The business perspective,” Decision Support Systems, vol. 51,no. 1, pp. 176-189, 2011. Article (CrossRef Link)

[11] S. C. Park and S. Y. Ryoo, "An empirical investigation of end-users' switching toward cloud computing: A two factor theory perspective," Computers in Human Behavior, vol. 29, no. 1, pp. 160-170, 2013. Article (CrossRef Link)

[12] W. Stephenson, The Study of behavior: Q-technique and its methodology, Chicago, USA: University of Chicago Press, 1953.

[13] Schlinger, “Ques on Q-technique,” Journal of Advertising Research, vol. 9, pp. 53-60, 1969. Article (CrossRef Link)

[14] B. McKeown and D. Thomas D, Q-methodology, Beverly Hills, CA: Sage, 1988.

[15] S. R. Brown, Political Subjectivity: Applications of $Q$ methodology in political science, London: Yale University Press, 1980.

[16] S. R. Brown, “A primer on Q methodology,” Operant Subjectivity, vol. 16, no. 3/4, pp. 91-138, 1993. Article (CrossRef Link)

[17] H. G. Kim, $Q$ methodology: Philosophy, theories, analysis, and application, Seoul: Communication Books Inc., 2008.

[18] J. V. Exel and G. D. Graaf, "Q methodology: A sneak preview,” pp. 1-25, 2005. Article (CrossRef Link)

[19] K. Y. Kim and H. G. Kim, "A study on consumer preference typologing toward sharing economy service models based on collaborative consumption: A strategic approach to marketing communications," Journal of Koerean Society for the Scientific Study of Subjectivity, vol. 27, pp. 23-40, Dec. 2013. Article (CrossRef Link)

[20] B. Berelson and M. Janowitz, The evaluation of public opinion. Reader in Public Opinion and Communication, NY, USA: Free Press, 1966.

[21] R. D. Wimmer and J. R. Dominick, Mass media research: An introduction. Boston, MA, USA: Wadsworth Cengage Learning, 1994.

[22] K. Y. Kim and B. G. Lee, "Marketing insights for mobile advertising and consumer segmentation in the cloud era: A Q-R hybrid methodology and practices," Technological Forecasting and Social Change, vol. 91, pp. 78-92, 2015. Article (CrossRef Link) 
[23] H. G. Kim, "P samples and Q sorting," Journal of Korean Society for the Scientific Study of Subjectivity, vol. 15, pp. 5-19, 2007.

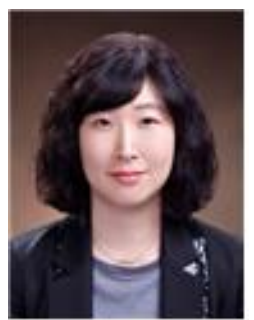

Ki Youn Kim is a professor in the Department of Marketing Big data at Mokwon University, Daejeon, Republic of Korea. She received her Ph.D. and M.A. degree in Management of Information Systems at Yonsei University. She conducted researches on the fields of BI\&A (business intelligence and analytics), big data, marketing technology, customer behavior and ICT policies and industries.

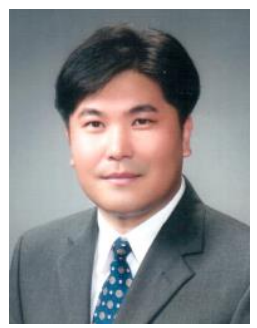

In Kuk Song is a professor in the Department of Management at Dankook University, Suji, South Korea. He has received a B.S. degree, majoring in Computer Science at University of Tennessee. He was also conferred M.S. and D.S. degrees in the field of Information \& System Management at George Washington University. His current research interests include Information Strategy, IT Business and Strategy. 